\title{
Hydrolysis of $\alpha$-lactalbumin by cardosin A immobilized on highly activated supports
}

\author{
Rui M. Barros ${ }^{\text {a }}$, Clara I. Extremina ${ }^{\text {a }}$, Inês C. Gonçalves ${ }^{a}$, Beatriz O. Braga ${ }^{a}$, \\ Victor M. Balcão ${ }^{\mathrm{a}, \mathrm{b}}$, F. Xavier Malcata ${ }^{\mathrm{a}, *}$ \\ ${ }^{a}$ Escola Superior de Biotecnologia, Universidade Católica Portuguesa, Rua Dr. António Bernardino de Almeida, P-4200-072 Porto, Portugal \\ ${ }^{\mathrm{b}}$ Centro de Bioengenharia e FármacoClínica, Universidade Fernando Pessoa, Praça 9 de Abril, P-4249-004 Porto, Portugal
}

Keywords: Enzyme; Protease; Agarose; Attachment; Structural stabilization; Dairy foods; $\alpha$-Lactalbumin; Cardosin

\begin{abstract}
In the present research effort, production of derivatives of cardosin A (a plant protease) encompassing full stabilization of its dimeric structure has been achieved, via covalent, multi-subunit immobilization onto highly activated agarose-glutaraldehyde supports. Boiling such enzyme derivatives in the presence of sodium dodecyl sulfate and $\beta$-mercaptoethanol did not lead to leaching of enzyme, thus providing evidence for the effectiveness of the attachment procedure. Furthermore, the cardosin A derivatives prepared under optimal conditions presented ca. half the specific activity of the enzyme in soluble form, and were successfully employed at laboratory-scale trials to perform (selective) hydrolysis of $\alpha$-lactalbumin ( $\alpha$-La), one of the major proteins in bovine whey. Hydrolysates of $\alpha$-La were assayed for by the OPA method, as well as by FPLC, SDS-PAGE and HPLC. Thermal inactivation of the immobilized cardosin A was also assessed at 40,50 and $55{ }^{\circ} \mathrm{C}$; at these temperatures, no thermal denaturation took place during incubation for $48 \mathrm{~h}$. The highest degree of hydrolysis was attained by $5 \mathrm{~h}$ reaction, at $55^{\circ} \mathrm{C}$ and $\mathrm{pH}$ 5.2. SDS-PAGE of $\alpha$-La hydrolysates displayed bands corresponding to low molecular weight peptides. Our results suggest that cardosin A in immobilized form is a good candidate to bring about proteolysis in the dairy industry, namely in whey processing.
\end{abstract}

\section{Introduction}

Whey, quantitatively the most important by-product of the dairy industry, has a potential high-added value owing to its protein content, namely $\alpha$-lactalbumin $(\alpha-\mathrm{La})$; this protein, with a molecular weight of $14.2 \mathrm{kDa}$, is the second most abundant and accounts for ca. $20-25 \%$ of the total bovine whey proteins. Native $\alpha$-La has been reported to be susceptible to proteolytic attack by commercial enzymes (e.g. [1]) and by plant enzymes (e.g. [2-4]), while it is the most heat-resistant whey protein [5]. Enzymatic hydrolysis of whey protein concentrates, following thermal processing, may eventually lead to more digestible and functional peptides; when incorporated into food formulæ, they will likely bring about favorable contributions to texture and taste, as well as reduction of allergenic effects [6-8].

Aqueous extracts of dried flowers of Cynara cardunculus possess three acid proteases (I, II and III), currently termed cardosins [9-12]; of those, forms I and II are similar to each other, and thus jointly denominated cardosin $\mathrm{A}$, whereas

\footnotetext{
* Corresponding author. Tel.: +351-2255-80004; fax: +351-2250-90351.
}

E-mail address: xmalcata@esb.ucp.pt (F.X. Malcata). form III is denominated cardosin B [13]. Each cardosin consists of two subunits, with apparent molecular weights 31 and $15 \mathrm{kDa}$ for cardosin $\mathrm{A}$, and 34 and $14 \mathrm{kDa}$ for cardosin $\mathrm{B}$ $[14,15]$. Esteves [16] reported that cardosins A and B possess catalytic activities and specificities similar to those of chymosin and pepsin, respectively, which are widely known to be the main components of animal rennets used in the dairy industry. Cardosins are aspartic acid proteases; in general, this class of enzymes cleaves peptide bonds flanked by bulky hydrophobic amino acid residues [13,17]. Note that the crude enzyme preparations from the dried flowers of $C$. cardunculus have for ages been successfully employed in traditional cheese making in Portugal and bordering regions of Spain.

Proteases can be immobilized without major loss of catalytic activity, and the potential of a crude mixture of immobilized plant enzymes for peptide release has been demonstrated elsewhere [18]. The simplified working protocols that become possible when immobilized enzymes are used, their long-term stability and their successful reutilization are among the advantages of such an approach relative to their soluble counterparts. Since proteases are often expensive, especially at high degrees of purity, development of strategies that will produce structural and functional 
stabilization thereof via immobilization may increase their industrial applicability; one example is in bioreactors designed to break down proteins in dairy industry effluents, down to functional peptides or even to fermentable nitrogen sources. Such structural stabilization would prevent release of enzyme molecules (or subunits, as is the case of dimeric cardosin A) to the reaction medium, and hence to the process effluent (thus greatly decreasing the risks of environmental contaminations), whereas functional stabilization would increase the useful life of the bioreactor (hence greatly decreasing the costs of operation).

Agarose gels are quite popular because they are almost ideal supports for the preparation of matrices in affinity chromatography and in enzyme immobilization. Agarose beads consist of a three-dimensional network of highly hydrophilic and extremely inert fibers, the surface of which is essentially covered by hydroxyl groups; these groups can easily be activated for covalent immobilization of enzymes, thus providing a high specific area for immobilization [19-23].

In the present research work, cardosin A extracted from the dried flowers of $C$. cardunculus was duly purified, and then covalently attached onto highly activated agaroseglutaraldehyde supports. These beads were used to catalyze the hydrolysis of $\alpha$-La at various temperatures.

\section{Materials and methods}

\subsection{Materials}

\subsubsection{Enzyme}

The enzyme used consisted of cardosin A (purified as described below), after aqueous extraction from flowers of C. cardunculus L., as described in detail in [3].

\subsubsection{Chemicals}

Agarose beads (6BCL, i.e. cross-linked to 6\%) were obtained from HISPANAGAR (Burgos, Spain). Glycidol (2,3-epoxy-1-propanol), boric acid, lauryl sulfate (sodium dodecyl sulfate), $\beta$-mercaptoethanol, ammonium persulfate, sodium thiosulfate, TEMED $\left(N^{\prime} N^{\prime} N^{\prime} N\right.$-tetramethylethylenediamine), ethylenediamine, formaldehyde, TRIZMA ${ }^{\circledR}$ hydrochloride, Schiff's reagent (fuchsin-sulfate), sodium acetate trihydrate, sodium hydroxide, glycerol ( $87 \%$ in water) and sodium borohydride were all purchased from Sigma (St. Louis, MO, USA); trifluoroacetic acid (TFA), $\mathrm{CCl}_{3} \mathrm{COOH}$ (TCA), $\mathrm{NaIO}_{4}, \mathrm{Na}_{2} \mathrm{HPO}_{4}, \mathrm{NaH}_{2} \mathrm{PO}_{4}, \mathrm{C}_{6} \mathrm{H}_{8} \mathrm{O}_{7} \cdot \mathrm{H}_{2} \mathrm{O}$, $\mathrm{C}_{6} \mathrm{H}_{5} \mathrm{Na}_{3} \mathrm{O}_{7}$ and $\mathrm{NaN}_{3}$ were purchased from Merck (Darmstadt, Germany). Glutaraldehyde aqueous solution (25\%, v/v) was purchased from Fluka (Steinheim, Germany). A mixture of molecular weight standards for FPLC, viz. aldolase $(158 \mathrm{kDa})$, bovine serum albumin $(67 \mathrm{kDa})$, ovalbumin (43 kDa), $\beta$-lactoglobulin (36 kDa), $\alpha$-La (14.4 kDa) and ribonuclease $(13.7 \mathrm{kDa})$, and a mixture of low molecular weight markers for electrophoresis, viz. globin $(16.9 \mathrm{kDa})$, globin I + II (14.4 kDa), globin I + III (10.7 kDa), globin $(8.2 \mathrm{kDa})$, globin II $(6.2 \mathrm{kDa})$ and globin III $(2.5 \mathrm{kDa})$, were purchased from Pharmacia LKB Biotechnology (Uppsala, Sweden). Filter paper $(0.22 \mu \mathrm{m})$ was obtained from Nalgene (New York, NY, USA), and nonsterile filters $(0.45 \mu \mathrm{m})$ from Nucleopore (Cambridge, MA, USA). Tricine ( $N$-tris(hydroxymethyl)methylglycine) was purchased from Bio-Rad (Hercules, CA, USA). Dialysis tubing with MW cutoff of $10 \mathrm{kDa}$ was purchased from Sigma. Tap water was purified in a Milli-Q Plus 185 system (Molsheim, France) to a final conductivity of ca. $18.2 \mathrm{M} \Omega / \mathrm{cm}$. The solvents used were all analytical grade or better, and were used without further purification; $\mathrm{NaN}_{3}(0.4 \%$, w/v) was added to all solutions for preservation purposes.

\subsubsection{Analytical equipment}

The spectrophotometric readings were carried out using quartz cuvettes in an UV-Vis spectrophotometer, model UV-Vis 1240 from Shimadzu (Kyoto, Japan), modified to include a thermostatted magnetic stirrer unit for the cuvette. The crude plant extract and the purified cardosin A were lyophilized in a CHRIST ALPHA 1-4 freeze-dryer from Braun Biotech (Braunschweig, Germany). High density gels were run using a PhastSystem unit (Pharmacia LKB Biotechnology). SDS-PAGE was performed in a mini-Protean II xi vertical slab-gel unit from Bio-Rad (Watford, UK), coupled with a model 1000/500 power supply also from Bio-Rad and a refrigerated water bath from Julabo Labortechnik (Seelbach, Germany). All electrophoresis gels were scanned in a GS-700 Imaging Densitometer from Bio-Rad (Hercules, CA, USA), using the Molecular Analyst software (version 1.4) also from Bio-Rad. All support preparations and enzyme immobilization procedures were carried out in a Móvil Rod end-over-end agitator from Selecta (Barcelona, Spain). The FPLC system (Pharmacia LKB Biotechnology) consisted of two P-500 positive displacement pumps, an electrically powered MV-7 motorized valve, a gel filtration column pre-packed with Superose 12 HR 10/30 and an UVII single-path spectrophotometer monitor. A gel filtration chromatography column (Sephacryl S-200 HR 16/60) was also obtained from Pharmacia LKB Biotechnology. The HPLC chromatographic system used was an Alliance ${ }^{\mathrm{TM}}$ model from Waters (St. Quentin-Yvelines, France), equipped with a solvent delivery system with two pumps (programable solvent module 2690), an auto injector and a photodiode array detector (PDA system model 996), and a reversed-phase Lichrosphere $\mathrm{C}_{8}$ column $(4.6 \mathrm{~mm} \times 250 \mathrm{~mm}$, with a $5 \mu \mathrm{m}$ particle size filling) (from Merck, Darmstadt, Germany) coupled with a Lichrocart 4-4 guard column also from Merck. All data acquisition and analysis were performed using the chromatographic system software Millennium ${ }^{\mathrm{TM}}$ 32 (version 4.0) also from Waters.

\subsection{Experimental procedures}

\subsubsection{Extraction and purification of cardosin $A$}

The crude enzyme extract was prepared by macerating ca. $7 \mathrm{~g}$ of stylets and stigmae of dried flowers of $C$. cardunculus 
in $70 \mathrm{ml}$ of $100 \mathrm{mM}$ sodium citrate buffer (pH 3.0), as described by Faro [11]. After centrifugation at $10,000 \times g$ for $5 \mathrm{~min}$, the resulting supernatant was collected, dialyzed at $4{ }^{\circ} \mathrm{C}$ against a large volume of deionized water for $48 \mathrm{~h}$ (to remove citrate) using dialysis tubing with MW cutoff of $10 \mathrm{kDa}$ (Sigma), and finally lyophilized. The purification step was as follows [3]: the aforementioned aqueous extract was centrifuged at $10,000 \times g$ for $5 \mathrm{~min}$ at $4{ }^{\circ} \mathrm{C}$, and $5 \mathrm{ml}$ of the resulting supernatant were loaded onto a gel filtration chromatography column (Pharmacia LKB Biotechnology) in order to recover the peak accounted for by cardosins A and B. This step was repeated as many times as necessary to obtain preparative amounts of partially purified extract prior to lyophilization. Following gel filtration, the partially purified extract was reconstituted in a small amount of Tris- $\mathrm{HCl}$ buffer ( $\mathrm{pH} 7.6$ ), and $20 \mathrm{mg}$ of extract was subject to further purification by weak anion exchange chromatography (column DEAE, from Bio-Rad), using a linear gradient of $0-0.5 \mathrm{M} \mathrm{NaCl}$ in $250 \mathrm{ml}$ of $0.2 \mathrm{M}$ Tris- $\mathrm{HCl}$ buffer ( $\mathrm{pH} 7.6$ ), at a flow rate of $1.2 \mathrm{ml} / \mathrm{min}$. This chromatographic step was repeated as many times as needed to yield preparative amounts of pure cardosin A. The fraction of cardosin A was duly collected, and dialyzed for $48 \mathrm{~h}$ at $4{ }^{\circ} \mathrm{C}$ against a large volume of deionized water (so as to remove Tris and citrate) using dialysis tubing with a MW cutoff of $10 \mathrm{kDa}$. Pure cardosin A was finally frozen at $-20^{\circ} \mathrm{C}$ and lyophilized. After collection, the presence of cardosin A was double checked by electrophoresis (using Phastgel-High density gels).

\subsubsection{Determination of total protein content of cardosin A}

The protein content of the pure cardosin $\mathrm{A}$ in aqueous solution was determined using the Micro Protein Determination kit No. 690 (Sigma). The assays, carried out in triplicate, yielded $0.44 \pm 0.08 \mathrm{mg} / \mathrm{ml}$.

\subsubsection{Determination of catalytic activity of cardosin $A$}

The proteolytic activity of the pure cardosin A was determined based on the procedure described by Tomarelli et al. [24], which involves digestion of azocasein (obtained from a casein chromophore and dinitrogenated arylamine) at $25^{\circ} \mathrm{C}$, thus producing colored reaction products (that are soluble in trichloroacetic acid, TCA); absorbance of the supernatant, after centrifugation, was measured at $440 \mathrm{~nm}$. The proteolytic activity of cardosin A, expressed as the variation of absorbance at $440 \mathrm{~nm}$ per mass of protein per unit time, was $1.27 \pm 0.12 \mathrm{AU} /\left(\mathrm{g}_{\text {protein }} \min \right)$.

\subsubsection{Preparation of agarose-glutaraldehyde supports for cardosin A}

The procedure followed here was described initially by Guisán [25], and later complemented with slight modifications [22,23]: $26.25 \mathrm{~g}$ of agarose beads (6BCL, previously washed with plenty of deionized water) were weighed into a plastic flask, and water was added to a final volume of $45 \mathrm{ml}$ ( $0.7 \mathrm{~g}$ of agarose is roughly equivalent to $1 \mathrm{ml})$. Following mild homogenization, $12.5 \mathrm{ml}$ of $1.7 \mathrm{M} \mathrm{NaOH}$ containing
$356 \mathrm{mg} \mathrm{NaBH}$ (acting as reducing agent) was slowly added. The flask was then placed in an ice bath, and glycidol was added dropwise (since it promotes a highly exothermic reaction) to a final concentration of $2 \mathrm{M}$ (i.e. $9 \mathrm{ml}$ glycidol was added). The mixture was then paddle-agitated at room temperature (ca. $25^{\circ} \mathrm{C}$ ) for $15-18 \mathrm{~h}$, and the activated gel thus obtained was finally washed with $500 \mathrm{ml}$ deionized water. To $26.25 \mathrm{~g}$ of activated gel (i.e. $37.5 \mathrm{ml}_{\mathrm{gel}}$ ), $1 \mathrm{ml}$ of aqueous $100 \mathrm{mM} \mathrm{NaIO}_{4}$ per $\mathrm{ml}_{\text {gel }}$ was added (so as to reach the level of $100 \mu \mathrm{mol}_{\text {aldehyde groups }} / \mathrm{ml}_{\text {gel }}$ ). The gel was then suspended in water to a final volume of $375 \mathrm{ml}$, and oxidation was allowed to proceed for $1.5-2 \mathrm{~h}$ (under paddle-agitation); the gel was then washed with $500 \mathrm{ml}$ of deionized water. Confirmation of the presence of aldehyde groups in the gel was via addition of a few milligrams of (oxidized) gel to ca. $200 \mu \mathrm{l}$ of Schiff's reagent in an eppendorf vial, which produced the expected pinky-purple coloration; $25 \mathrm{~g}$ of this (just prepared) glyoxyl-agarose gel were weighed into a plastic beaker and $143 \mathrm{ml}$ of $2 \mathrm{M}$ ethylenediamine ( $\mathrm{pH} 10$ ) were added. Following mild paddle-agitation for ca. $2 \mathrm{~h}, 1.429 \mathrm{~g}$ of $\mathrm{NaBH}_{4}$ was added and the paddle-agitation was maintained for an extra $2 \mathrm{~h}$. The (amino) gel thus produced was then sequentially washed with $1000 \mathrm{ml}$ of $0.1 \mathrm{M}$ sodium acetate (pH 4) (to eliminate sodium borohydride), $1000 \mathrm{ml}$ of $0.1 \mathrm{M}$ boric acid (pH 9) (to reduce electrostatic interactions and eliminate excess ethylenediamine), and finally excess of deionized water. To $2.5 \mathrm{~g}$ of this amino gel, $2.8 \mathrm{ml}$ of $200 \mathrm{mM} \mathrm{NaH}_{2} \mathrm{PO}_{4}$ was added and the $\mathrm{pH}$ of the resulting mixture was adjusted to 7.0 using dilute $\mathrm{NaOH} ; 4.2 \mathrm{ml}$ of aqueous $25 \%$ (v/v) glutaraldehyde was then added, and the $\mathrm{pH}$ of the resulting solution was adjusted once again to 7.0. The mixture was subsequently paddle-agitated overnight in a gentle fashion, and the resulting gel was washed with $500 \mathrm{ml}$ deionized water.

\subsubsection{Immobilization of cardosin A onto agarose-glutaraldehyde supports}

The preparation of these derivatives essentially followed the procedure described by Balcão et al. [22,23] and Lamas et al. [18]; it encompassed addition of $4 \mathrm{ml}$ of aqueous $87 \%$ (v/v) glycerol into a plastic flask, followed by homogenization with $4 \mathrm{ml}$ of $25 \mathrm{mM} \mathrm{NaH}_{2} \mathrm{PO}_{4}$ (pH 7.0). To the resulting solution, $22 \mathrm{mg}$ of pure cardosin A was added. Following mild homogenization, $500 \mathrm{mg}$ of agarose-glutaraldehyde (6BCL, after activation with $40 \mu \mathrm{mol}_{\text {aldehyde groups }} / \mathrm{ml}_{\text {gel }}$ ) was added to this solution, and the flask was stoppered tightly and placed in an end-over-end agitator kept at $4{ }^{\circ} \mathrm{C}$. Samples of both the suspension and the supernatant were regularly withdrawn and assayed for activity, together with the blank (which consisted of reconstituted enzyme solution withdrawn prior to addition of the support). In order to discontinue the immobilization procedure (when the activity of the supernatant was sufficiently low), the derivative was reduced via addition of $1 \mathrm{mg}$ of $\mathrm{NaBH}_{4}$ per milliliter of gel (to transform the Schiff's bases obtained into covalent bonds, therefore strengthening the bonds between enzyme and support), followed by mild paddle-agitation for ca. 
$30 \mathrm{~min}$. After this period, the derivative was washed with $100 \mathrm{ml}$ of deionized water.

\subsubsection{Analysis of stabilization of the quaternary structure of cardosin $A$}

The stabilization of the quaternary structure of dimeric cardosin A was confirmed by electrophoresis, after having boiled the derivatives in the presence of SDS. This treatment, suggested by Fernández-Lafuente et al. [26], releases from the support any enzyme subunit that was not covalently bound to it. Therefore, the presence of bands in the stained gel would indicate lack of stabilization; the bonds established between the enzyme and the support are indeed very stable secondary amino bonds, and stand still at $110^{\circ} \mathrm{C}$ in $6 \mathrm{M} \mathrm{NaCl}[21,27,28]$. High density gel electrophoresis was performed with disrupted agarose-glutaraldehyde derivatives, as well as with pure cardosin A and selected low molecular weight standards, using a PhastSystem unit and high density minigels $(50 \mathrm{~mm}$ high $\times 43 \mathrm{~mm}$ wide $\times 0.45 \mathrm{~mm}$ thick). For the preparation of samples, a pre-determined amount of cardosin A derivative (15 mg of gel, containing ca. $15.4 \mu g_{\text {protein }} / \mathrm{mg}_{\text {gel }}$ ) was placed in an Eppendorf vial, resuspended in $400 \mu \mathrm{l}$ of $100 \mathrm{mM}$ citrate buffer, and added with $100 \mu \mathrm{l}$ of $10 \%(\mathrm{w} / \mathrm{v})$ SDS (to ensure elimination of shape and charge effects). The vial was subsequently heated to $95^{\circ} \mathrm{C}$ for $10 \mathrm{~min}$ in a heating block and cooled to near room temperature. Approximately $4 \mu \mathrm{l}$ of solution of denatured sample (containing ca. $10 \mu \mathrm{g}_{\text {protein }} / \mathrm{ml}$ ), pure cardosin A (ca. $10 \mu g_{\text {protein }} / \mathrm{ml}$ ) or markers, as appropriate, was poured in lined small pools before application onto the gel surface. After electrical resolution of the sample proteins, the gel was transferred to the development section of the PhastSystem unit and stained with Coomassie Blue R-250.

\subsubsection{Evaluation of thermal stability of immobilized cardosin A}

The thermal stability of the immobilized enzyme was assessed via preparation of suspensions in aqueous sodium citrate buffer solution ( $\mathrm{pH} \mathrm{5.2)}$ at the desired temperature, using $15 \mathrm{mg}$ of immobilized cardosin A derivative. This suspension was then assayed for activity, and subsequently placed in a water bath at either 40,50 and $55^{\circ} \mathrm{C}$. At selected time intervals, and after thorough mixing, $100 \mu$ l-aliquots were withdrawn and duly assayed for activity using the protocol described earlier: $900 \mu$ l of a $1.0 \mathrm{mg}_{\alpha-\mathrm{La}} / \mathrm{ml}$ solution was added, and the resulting solution was incubated at $55^{\circ} \mathrm{C}$ for at least $2 \mathrm{~h}$ before analysis by FPLC was in order.

\subsubsection{Hydrolysis of $\alpha$-lactalbumin by immobilized cardosin $A$}

The reactions were performed batchwise, employing a ratio of immobilized cardosin A to $\alpha$-La of $1 / 20$ (50 $\mathrm{mg}_{\text {derivative }}$ containing $770 \mu \mathrm{g}_{\text {immobilized cardosin } \mathrm{A}}$ ), up to the same overall volume of reaction medium $(15 \mathrm{mg} \alpha-\mathrm{La}$ in $15 \mathrm{ml}$ of
$100 \mathrm{mM}$ citrate buffer, $\mathrm{pH} 5.2$ ), at 40,50 and $55^{\circ} \mathrm{C}$. All reactions were performed at $\mathrm{pH} 5.2$, in a jacketed glass beaker thermostatted via a recirculating water bath equipped with an orbital shaker set at $100 \mathrm{rpm}$. Samples were withdrawn in duplicate at selected time intervals, and duly prepared both for OPA, SDS-PAGE and FPLC analyses. Samples $(0.5 \mathrm{ml})$ withdrawn for SDS-PAGE analysis were immediately added with $100 \mu \mathrm{l}$ of disruption buffer in an Eppendorf vial and heated to $95^{\circ} \mathrm{C}$ for $10 \mathrm{~min}$. After cooling down to room temperature, the vials containing the denatured samples were centrifuged at $10,000 \times g$ for $5 \mathrm{~min}$ and subsequently frozen until analysis. Samples $(1.0 \mathrm{ml})$ withdrawn for FPLC analyses were immediately frozen at $-80^{\circ} \mathrm{C}$, and stored at that temperature until analysis was in order. Samples withdrawn for OPA analysis amounted to ca. $20 \mu 1$ each.

\subsubsection{Electrophoresis of cardosin A-mediated $\alpha$-La hydrolyzates}

For the preparation of samples, $500 \mu \mathrm{l}$ of the reaction medium (withdrawn at regular time intervals) was poured into Eppendorf vials, into which $100 \mu$ l of $10 \%$ (w/v) SDS was added. The vials were subsequently heated to $95^{\circ} \mathrm{C}$ for ca. $10 \mathrm{~min}$ in a heating block, cooled to near room temperature and centrifuged at $10,000 \times g$ for $10 \mathrm{~min}$. A solution containing SDS, $\beta$-mercaptoethanol, sucrose and bromophenol blue was then added to the supernatant of said samples, and these were further incubated in a heating block to $95^{\circ} \mathrm{C}$ for $5 \mathrm{~min}$. Hydrolysis of the main proteins was checked by tricine-SDS-PAGE (16.5\%), at constant voltage and current on the stacking gel $(80 \mathrm{~V}$ and $80 \mathrm{~mA})$, the spacer gel $(150 \mathrm{~V}$ and $100 \mathrm{~mA})$ and the separation gel $(150 \mathrm{~V}$ and $100 \mathrm{~mA})$, at $19{ }^{\circ} \mathrm{C}$ for ca. $3 \mathrm{~h}$; after this period, the gels were stained with Coomassie Blue R-250. All gels were scanned in an imaging densitometer, using a green filter, and further analysed (integration of bands) using the image analysis software Molecular Analyst ${ }^{\mathrm{TM}}$. Band intensities were transformed into peak areas, and values of measurements made in triplicate, for all running conditions tested, were averaged to yield data points.

\subsubsection{FPLC analysis of cardosin A-mediated $\alpha$-La hydrolyzates}

The reaction samples were assayed by Fast Protein Liquid Chromatography (FPLC), according to the procedure described by [3]. At pre-selected time intervals, $1.5 \mathrm{ml}$-aliquots were withdrawn from the reaction medium, poured into Eppendorf vials and immediately frozen at $-80^{\circ} \mathrm{C}$. Right before analysis, the vials were thawed and the contents filtered through $0.45 \mu \mathrm{m}$-nylon membrane filters. Aliquots $(100 \mu \mathrm{l})$ of the clear solution were then promptly injected into the FPLC column; detection of the proteins in the eluate was by continuous recordings of absorbance at $280 \mathrm{~nm}$. Each analytical determination was carried out in duplicate, and the average was used as a data point. 


\subsubsection{HPLC analysis of cardosin A-mediated \\ $\alpha$-La hydrolyzates}

Reaction samples were assayed by High Performance Liquid Chromatography (HPLC) according to the procedure described by [3]; the sample vials were kept at $10^{\circ} \mathrm{C}$ in the refrigerated autosampler. An injection loop of $100 \mathrm{ml}$ was used. The hydrolyzates were resolved in a reversed-phase Lichrosphere $\mathrm{C}_{8}$ column coupled with a Lichrocart 4-4 guard column. Separations were performed using a mixture of two solvents, solvent A $(0.1 \%$ TFA in water) and solvent B $(0.1 \%$ TFA in acetonitrile), under a gradient program (the column was equilibrated with solvent $\mathrm{A}$ and eluted with $100 \%$ (v/v) A for the first $5 \mathrm{~min}$, a linear gradient to $50 \%$ (v/v) B over $55 \mathrm{~min}, 50 \%(\mathrm{v} / \mathrm{v}) \mathrm{B}$ over $6 \mathrm{~min}$, a linear gradient to $60 \%$ $(\mathrm{v} / \mathrm{v}) \mathrm{B}$ over $4 \mathrm{~min}$ and $60 \%(\mathrm{v} / \mathrm{v}) \mathrm{B}$ over $3 \mathrm{~min})$. The flow rate was $0.75 \mathrm{ml} / \mathrm{min}$ and the absorbance was recorded at $214 \mathrm{~nm}$.

\subsubsection{Degree of hydrolysis of cardosin A-mediated $\alpha$-La hydrolyzates}

The degree of hydrolysis was determined by quantifying the increase of free amino groups in the resulting hydrolyzates via reaction with ortho-phthaldialdehyde (OPA), by absorbance measurement at $340 \mathrm{~nm}$ [29]. The degree of hydrolysis, DH (\%), was obtained by dividing the amount of $\alpha$-amino groups released $(n)$ by the total number of peptide bonds in $\alpha$-La $(N=122)$, and multiplying by $100 ; n$ was calculated as $n=\Delta \mathrm{Abs}_{340 \mathrm{~nm}}^{1 \mathrm{~cm}} / \varepsilon \times P \times \Phi[30]$, where $P$ (molar protein concentration) $=14,183 \mathrm{~mol} / \mathrm{dm}^{3}, \varepsilon$ (molar extinction coefficient of $\alpha$-La) $=6000 \mathrm{M}^{-1} \mathrm{~cm}^{-1}$ and $\Phi$ (dilution factor $)=1: 50(20 \mu$ l-aliquots were withdrawn from the reaction medium at regular intervals of time, and added to $1.0 \mathrm{ml}$ of OPA reagent).

\subsubsection{Statistical analyses of experimental data pertaining to hydrolysis}

Analysis of variance (ANOVA) of the data was performed using Microsoft Excel ${ }^{\mathrm{TM}} 2001$ for MacIntosh (Mac OS 9.2.2.); in all cases, the results were considered significant at the $1 \%$ level of significance.

\section{Results and discussion}

\subsection{Preparation of enzyme extract and characterization of pure cardosin A}

Special care was exercised so as to minimize variability throughout preparation of the crude extracts. Therefore, several batches of crude extract (obtained via manual grinding and subsequent aqueous extraction) were prepared in different days; all those extracts were eventually mixed together, and further dialyzed and lyophilized. Cardosin A was isolated and purified from this stock material. The proteolytic activity of pure cardosin A was $1.27 \pm 0.12 \mathrm{AU} /\left(\mathrm{g}_{\text {protein }} \mathrm{min}\right.$ ) (AU: Absorbance Units,
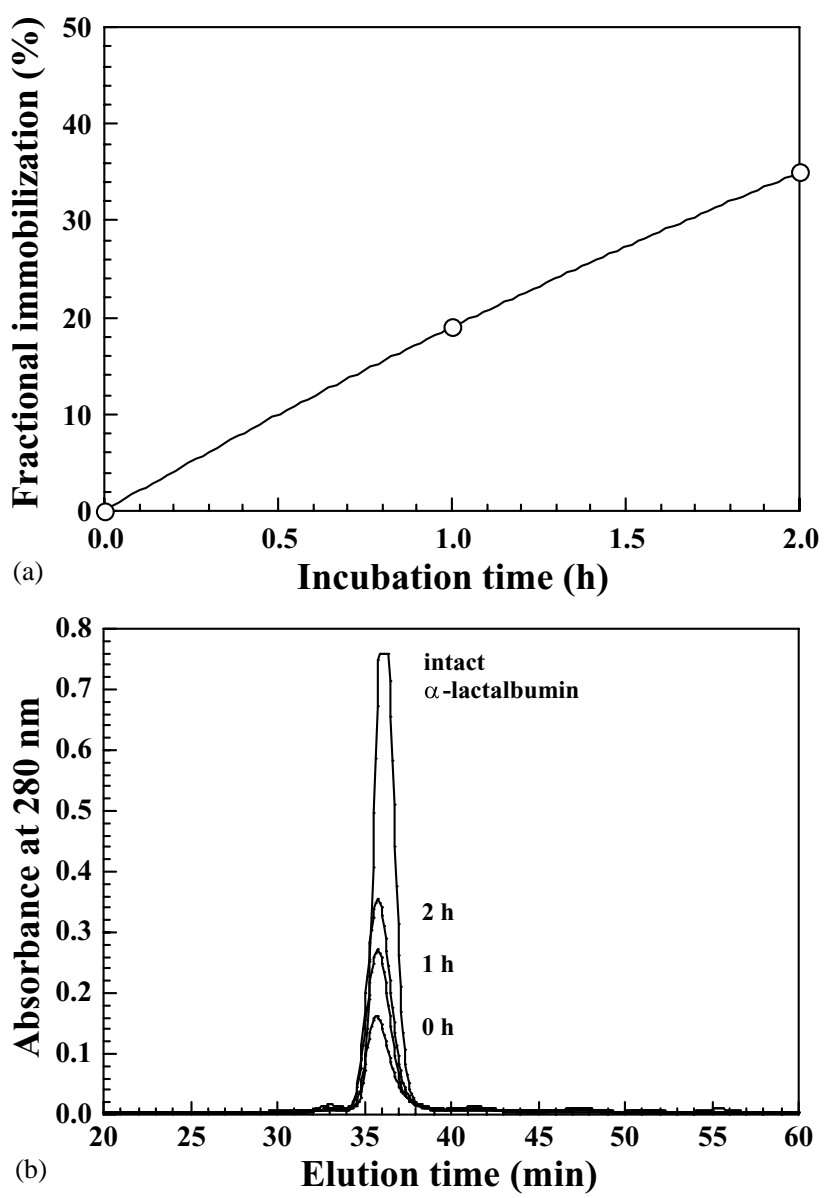

Fig. 1. Evolution with incubation time of (a) fractional immobilization of cardosin A (in percent protein) onto highly activated agarose-glutaraldehyde and (b) FPLC profile of residual $\alpha$-La after hydrolysis assay of the supernatant.

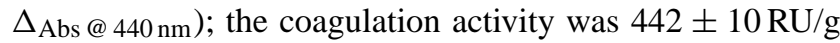
$(\mathrm{RU}=$ rennet units).

\subsection{Immobilization of cardosin A onto agarose-glutaraldehyde}

The results obtained pertaining to immobilization of cardosin A onto highly activated agarose 6BCL $(6 \%$ cross-linking)-glutaraldehyde support are displayed in Fig. 1a and b. Since a mild $\mathrm{pH}$ (viz. 7.0) prevails in the microenvironment of the enzyme, the native form of cardosin A remains essentially unaltered prior to contacting (and eventually attaching to) the support. This type of glutaraldehyde-activated support reacts primarily with the terminal amine moiety of proteins [25]; however, when the activation degree is high, as was the case in this research effort (see Fig. 1a), and the enzyme is allowed to contact the support for a long time (say, $2 \mathrm{~h}$, as is our case), more bonds will be established between enzyme and support [26,27,31]. When the environment is set at low ionic strength (as was actually the case), the enzyme molecules will first adsorb 
onto the support through the negatively charged portions of its surface, and then react through their terminal amino group [22,23,32]. The rate of immobilization was indeed high at low ionic strength, as can be noticed from inspection of Fig. 1a; this observation can be explained, at least to some extent, by a fast initial adsorption of enzyme onto the support. Fig. 1b displays the results of the hydrolysis of $\alpha$-La at $\mathrm{pH} 5.2$ and $55^{\circ} \mathrm{C}$ for $2 \mathrm{~h}$ effected by the supernatant prior to contacting the support, and after 1 and $2 \mathrm{~h}$ of contact with the support, as FPLC profiles of residual $\alpha$-La. As can be observed, the FPLC peak area at $0 \mathrm{~h}$ (i.e. no support contacting the enzyme solution) is quite small, and amounted to ca. $25 \%$ of the intact $\alpha$-La peak area; this means that the extent of hydrolysis was ca. $75 \%$, as all enzyme is present in the supernatant. After $1 \mathrm{~h}$ of contacting the enzyme with the support, the FPLC peak area increased to ca. $39 \%$ of the intact $\alpha$-La peak area; this means that the extent of hydrolysis was ca. $61 \%$, so some enzyme was already removed from solution and hence became attached to the support. The activity of the free enzyme solution did not decay during the time frame of the immobilization trials. After $2 \mathrm{~h}$ of contacting the enzyme with the support, the FPLC peak area attained ca. $51 \%$ of the intact $\alpha$-La peak area; this means that the extent of hydrolysis was ca. $49 \%$, so most enzyme was indeed successfully immobilized. As can be inferred from inspection of Fig. 1a, the yield of immobilization by $2 \mathrm{~h}$ was ca. $35 \%$ of the total protein made available to the support.

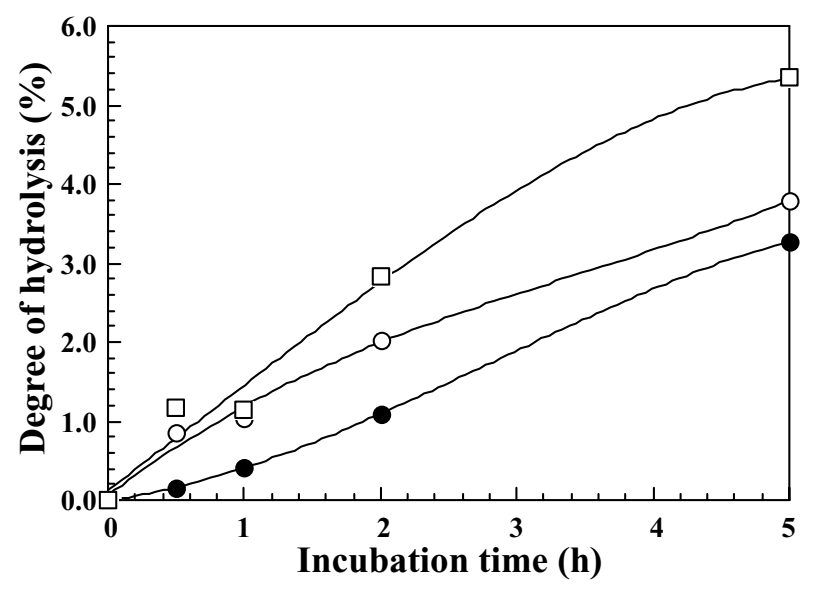

Fig. 3. Evolution of the degree of hydrolysis of $\alpha$-La throughout incubation effected by cardosin A derivatives at $40^{\circ} \mathrm{C}(\mathbf{O}), 50^{\circ} \mathrm{C}(\mathrm{O})$ and $55^{\circ} \mathrm{C}$ ( $\square$ ).

\subsection{Structural stabilization of the quaternary structure of immobilized cardosin A}

Fig. 2 depicts the SDS-PAGE analysis of the supernatants, obtained after boiling the free enzyme (lane 1) and the enzyme derivative (lane 2 ) in the presence of $\beta$-mercaptoethanol and SDS. No bands whatsoever can be found in the lane corresponding to the derivative, thus

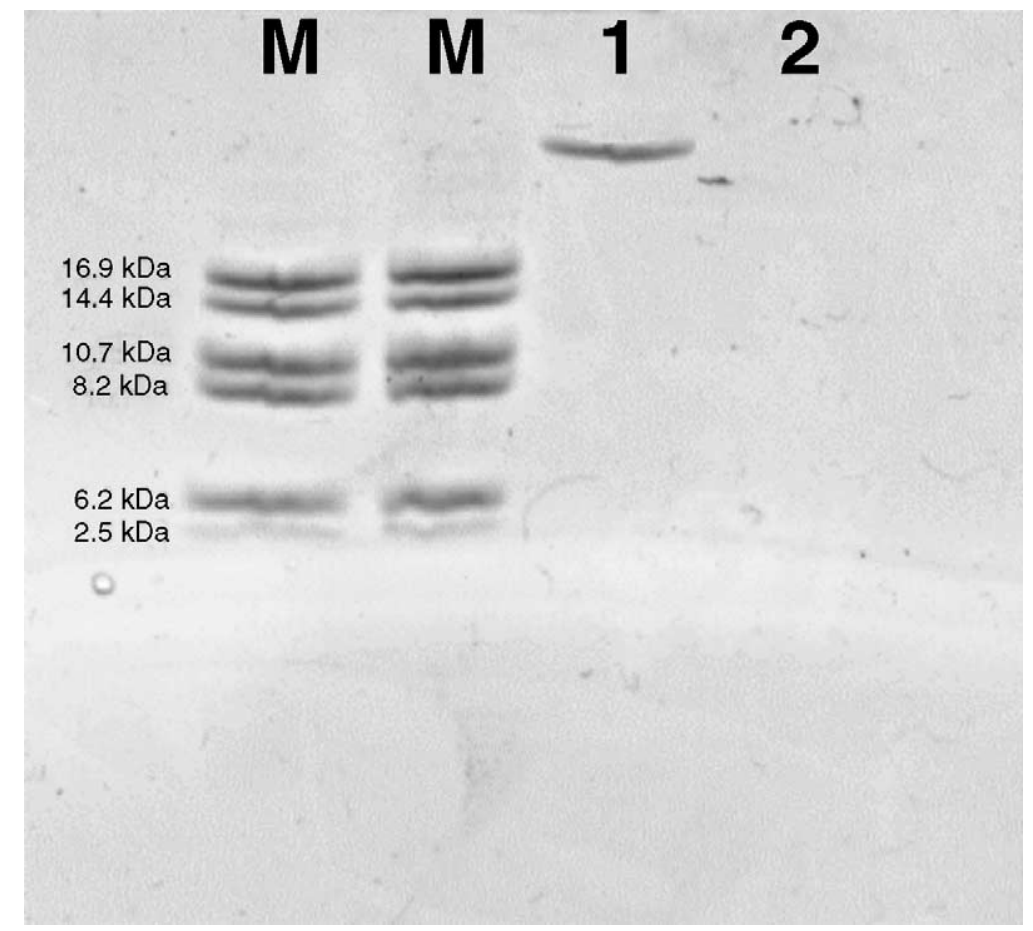

Fig. 2. Electrophoretogram of soluble (pure) cardosin A (lane 1) and corresponding agarose-glutaraldehyde derivative (obtained with $40 \mu$ mol aldehyde groups $/ \mathrm{ml}_{\text {support }}$ ) (lane 2), after boiling in the presence of $\beta$-mercaptoethanol and sodium dodecyl sulfate (lanes M: low molecular weight markers). 
providing evidence for the irreversibility of the immobilization procedure. Our results are in agreement with previous findings by Balcão et al. [22] and Lamas et al. [18]. The first step in the inactivation of dimeric enzymes is usually the dissociation of subunits, and concomitant unfavorable conformational changes; such steps could not take place in our case owing to full stabilization of the assembly of car-

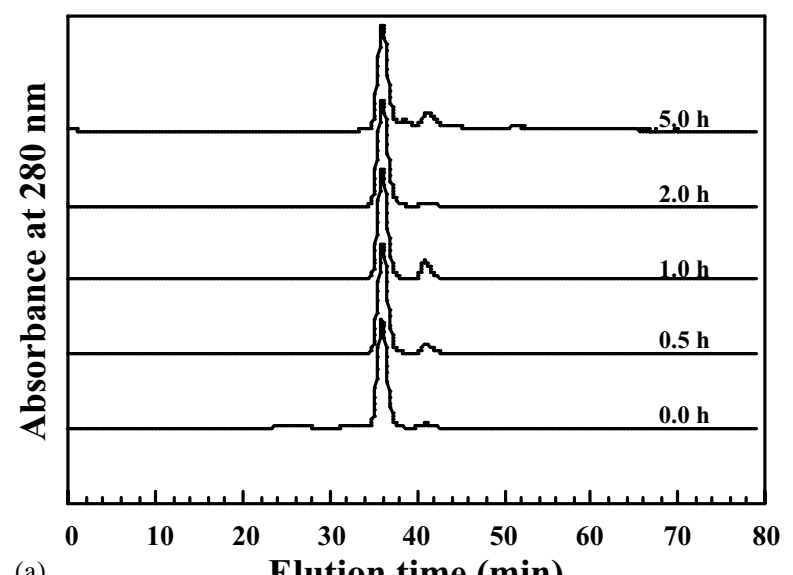

(a)
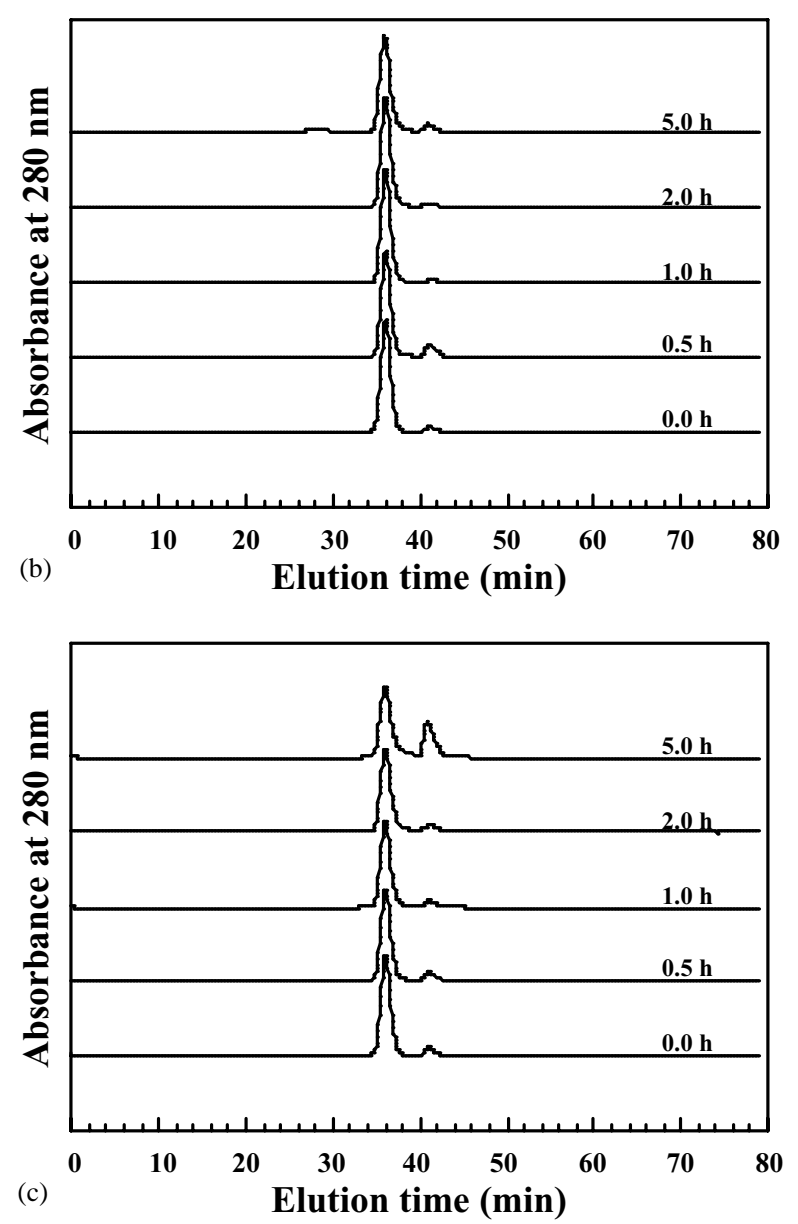

Fig. 4. FPLC profiles of the hydrolyzates of $\alpha$-La produced with immobilized cardosin A derivatives at $40^{\circ} \mathrm{C}\left(\right.$ a), $50^{\circ} \mathrm{C}$ (b) and $55^{\circ} \mathrm{C}$ (c). dosin A via multisubunit immobilization. Bearing in mind that protein molecules attached to the support, even via a single covalent bond, cannot be desorbed by the aforementioned treatment, any band appearing in the gel would in fact be likely associated with subunits of the dimeric enzyme molecules that were not covalently attached to the support [26].

\subsection{Thermal stability of immobilized cardosin A}

Thermal stability of the cardosin A agarose(6BCL)-glutaraldehyde derivative was checked at 40,50 and $55^{\circ} \mathrm{C}$. Following incubation for $48 \mathrm{~h}$ at each such temperature, the derivatives retained virtually $100 \%$ activity (results not shown); these results agree with Balcão et al. [22,33] and Lamas et al. [18].

\subsection{Hydrolysis of $\alpha$-lactalbumin by immobilized $\operatorname{cardosin} A$}

The results pertaining to the batch hydrolysis of $\alpha$-La, as catalyzed by immobilized cardosin A, are displayed in Figs. 3, 4a-c, 5, and 6a-c, for the three temperatures studied. The statistical analyses (ANOVA) show that there were significant differences between the DH (\%) attained during reaction at the three different temperatures. As can be realized from inspection of Fig. 3, the degree of hydrolysis increases with increasing temperature; it was highest $(5.3 \%)$ by $5 \mathrm{~h}$ at $55^{\circ} \mathrm{C}$. The percent variation of DH was much higher (ca. $40 \%$ ) when the temperature was increased from 50 to $55^{\circ} \mathrm{C}$ than when the temperature was increased from 40 to $50^{\circ} \mathrm{C}$ (only ca. 15\%). Figs. $4 \mathrm{c}$ and 5 show that the residual $\alpha$-La in the reaction medium decreases by ca. 20\%; FPLC analyses of the hydrolysates exhibit a significant increase in the second peak (at ca. 40 min elution time) at that temperature by $5 \mathrm{~h}$ reaction. Fig. 5 displays the evolution in residual $\alpha$-La in the reaction medium throughout the reaction timeframe

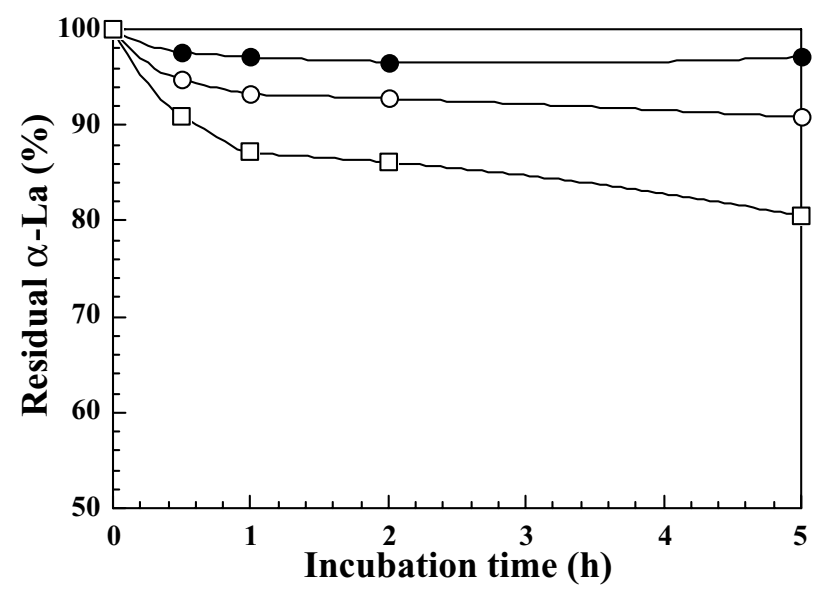

Fig. 5. Evolution of the fractional hydrolysis of $\alpha$-La in a batch reaction system consisting of $\alpha$-La in sodium-citrate buffer at $\mathrm{pH} 5.2$ and $40^{\circ} \mathrm{C}$ (○), $50^{\circ} \mathrm{C}(\bigcirc)$ and $55^{\circ} \mathrm{C}(\square)$. 
considered. The amount of $\alpha$-La decreases by only ca. $1.5 \%$ at $40{ }^{\circ} \mathrm{C}$, whereas the percent decrease attains ca. $10 \%$ at $50^{\circ} \mathrm{C}$. However, the percent decrease in the amount of $\alpha$-La in the reaction medium at $55^{\circ} \mathrm{C}$ was twice that at $50^{\circ} \mathrm{C}$. The percent activity retained by the enzyme derivative (see Fig. 1a and b), obtained as the ratio between the difference of peak areas of intact $\alpha-\mathrm{La}$ and that of remaining $\alpha-\mathrm{La}$ after $2 \mathrm{~h}$ of immobilization, to the peak area of intact $\alpha$-La was $35 \%$, a figure that is consistent with results by Balcão

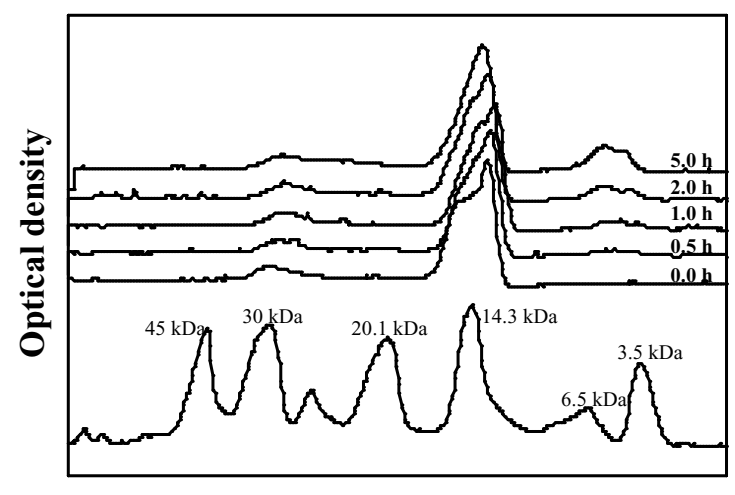

(a)

Longitudinal coordinate

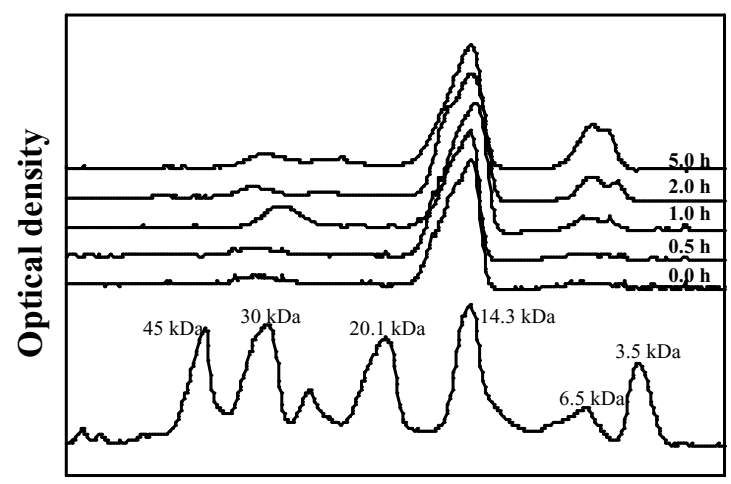

(b)

Longitudinal coordinate

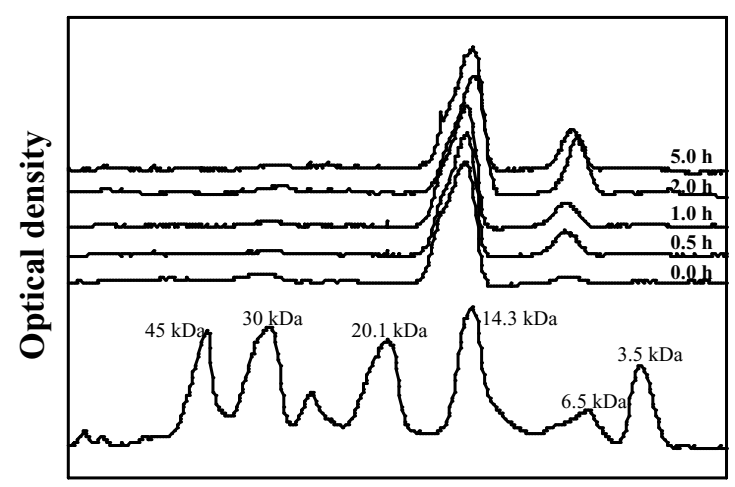

(c)

Longitudinal coordinate

Fig. 6. Normalized optical density profiles of the lanes in tricine-SDS-PAGE performed with molecular weight markers and samples withdrawn at selected time intervals, viz. $0,0.5,1.0,2.0$ and $5.0 \mathrm{~h}$, for reactions catalyzed by immobilized cardosin A derivatives at $40^{\circ} \mathrm{C}$ (a), $50^{\circ} \mathrm{C}$ (b) and $55^{\circ} \mathrm{C}$ (c), in a direction normal to that of the electrophoretic motion.

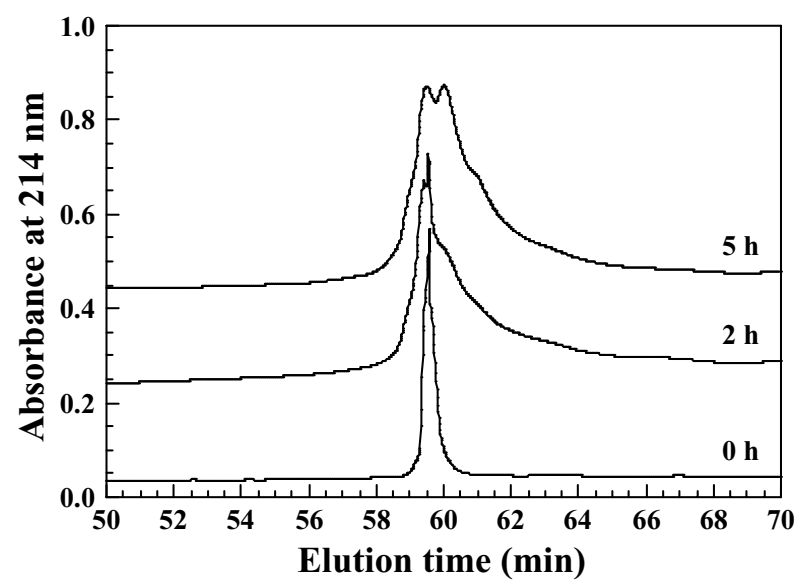

Fig. 7. HPLC profiles of the hydrolyzates of $\alpha$-La produced with immobilized cardosin $\mathrm{A}$ at $55^{\circ} \mathrm{C}$, at various incubation times.

et al. [22,23], Fernández-Lafuente et al. [26], Blanco and Guisán [31] and Blanco et al. [27]. Previous studies [18] have indicated that immobilization of a crude blend of cardosins leads to selective hydrolysis of $\alpha$-La; cardosin A has indeed been shown to possess a high affinity towards $\alpha$-La $\left(k_{\text {cat }}=0.102 \mathrm{~s}^{-1}\right)$ at $\mathrm{pH} 5.2$ [3]. Fig. 6 displays the normalized results of optical density analysis of the lanes in the gels obtained via tricine-SDS-PAGE analysis of samples, withdrawn from the reaction medium at pre-selected times during the course of reaction, as a function of the axial position in the gel. It can easily be seen that both the extent and the rate of hydrolysis are much higher at $55^{\circ} \mathrm{C}$ (see Fig. 6c), resulting from more dense bands in the stained gel after $5 \mathrm{~h}$ of reaction; this difference is confirmed by the highest value at $0 \mathrm{~h}$. The amounts of hydrolysis products, lumped as a band with MW of ca. $6.5 \mathrm{kDa}$, increase as reaction time elapses, as apparent by the increase of the optical density of such band (see Figs. 6a-c); this increase is particularly apparent at $55^{\circ} \mathrm{C}$ (see Fig. $6 \mathrm{c}$ ). Reverse-phase HPLC profiling of the hydrolyzates (see Fig. 7) exhibited, in addition to the peak corresponding to $\alpha$-La (by $0 \mathrm{~h}$ of reaction; $59.5 \mathrm{~min}$ elution time), one significant peak (by $5 \mathrm{~h}$ of reaction; 60 min elution time), hence suggesting the presence of a more hydrophobic peptide(s).

\section{Conclusions}

Cardosin A was, for the first time, successfully immobilized as pure enzyme onto highly activated supports; in this form, it retains the ability to hydrolyse $\alpha$-La, especially at $55^{\circ} \mathrm{C}$. Furthermore, immobilization onto highly activated, biocompatible agarose-glutaraldeyde allows full functional stabilization of its dimeric, three-dimensional architecture; the (nano)environment of each molecule of cardosin was virtually free from steric hindrance arising from the low molecular weight of the substrate $(\alpha-\mathrm{La})$. Crude blends of 
cardosins $\mathrm{A}$ and $\mathrm{B}$ obtained via plain aqueous extraction of the dried flowers of $C$. cardunculus have been (and still are) used in the manufacture of traditional Portuguese cheeses, and they are known to possess unique specificities. The results presented in this research effort are thus of potentially high value for whey processing on the commercial scale.

\section{Acknowledgments}

Financial support for RMB was through a Ph.D. fellowship by FCT (PRAXIS XXI BD/16037/98). The authors are grateful to Dr. José Manuel Guisán and Dr. Roberto Fernández-Lafuente (both affiliated with ICP/CSIC, Madrid) for specific technical training.

\section{References}

[1] Pintado MME, Pintado AE, Malcata FX. Controlled whey protein hydrolysis using two alternative proteases. J Food Eng 1999;42:1-13.

[2] Barros R, Ferreira CA, Silva SV, Malcata FX. Quantitative studies on the enzymatic hydrolysis of milk proteins brought about by cardosins precipitated by ammonium sulfate. Enzyme Microb Technol 2001;29:541-7.

[3] Barros RM, Malcata FX. Modelling of the kinetics of whey protein hydrolysis brought about by a purified enzyme extracted from Cynara cardunculus. Biotechnol Prog 2002;50:4347-56.

[4] Barros RM, Malcata FX. Modelling the kinetics of whey protein hydrolysis brought about by enzymes from Cynara cardunculus. J Agric Food Chem, in press.

[5] Donovan M, Mulvihill DM. Thermal denaturation and aggregation of whey proteins. Ir J Food Sci Technol 1987;11:87-100.

[6] Asselin J, Amiot J, Gauthier SF, Mourad W, Herbert J. Immunogenicity and allergenicity of whey protein hydrolysates. J Food Sci 1988;53:1208.

[7] Schmidt DG, Poll JK. Enzymatic hydrolysis of whey proteins. Hydrolysis of $\alpha$-lactalbumin and $\beta$-lactoglobulin in buffer solutions by proteolytic enzymes. Neth Milk Dairy J 1991;45:225.

[8] Bozar JJ, Martinez-Augustin O, Gil A. Nutritional and antigenic characterization of an enzymatic protein hydrolyzate. J Agric Food Chem 1995;43:872.

[9] Campos R, Guerra R, Aguiar M, Ventura O, Camacho L. Chemical characterization of proteases extracted from wild thistle (Cynara cardunculus). Food Chem 1990;35:89.

[10] Heimgartner U, Pietrzak M, Geertsen R, Brodelius P, Silva Figueiredo AC, Pais MSS. Purification and partial characterization of milk clotting proteases from flowers of Cynara cardunculus. Phytochemistry 1990;29:1405.

[11] Faro C. Purificação e caracterização físico-química da protease de Cynara cardunculus L. Ph.D. thesis. Portugal: Universidade de Coimbra; 1991.

[12] Cordeiro MC, Jakob E, Puhan Z, Pais MS, Brodelius PE. Milk clotting and proteolytic activities of purified cynarases from Cynara cardunculus - a comparison to chymosin. Milchwissenschaft 1992;47:683.

[13] Faro CJ, Moir AJ, Pires EV. Specificity of a milk-clotting enzyme extracted from the thistle Cynara cardunculus L.: action on oxidized insulin and к-casein. Biotechnol Lett 1992;14:841.

[14] Veríssimo P, Esteves C, Faro C, Pires E. The vegetable rennet from Cynara cardunculus $\mathrm{L}$. contains two proteinases with chymosin and pepsin-like specificities. Biotechnol Lett 1995;17:621.
[15] Veríssimo P, Faro C, Moir AJ, Lin Y, Tang J, Pires E. Purification, characterization and partial amino acid sequencing of two new aspartic proteinases from fresh flowers of Cynara cardunculus L. Eur J Biochem 1996;235:762.

[16] Esteves C. Estudo comparativo das características bioquímicas dos coalhos de Cynara cardunculus L., Cynara scolymus L., e Cynara humilis L. M.Sc. thesis. Portugal: Universidade de Coimbra; 1995.

[17] Fox PF, Singh TK, McSweeney PLH. Proteolysis in cheese during ripening. In: Varley J, Andrews AT, editors. Biochemistry of milk products. Cambridge, UK: Royal Society of Chemistry; 1994. p. $1-31$.

[18] Lamas EM, Barros RM, Balcão VM, Malcata FX. Hydrolysis of whey proteins extracted from Cynara cardunculus and immobilized onto highly activated supports. Enzyme Microb Technol 2001;28: 642-52.

[19] Medin AS. Studies on structure and properties of agarose. Ph.D thesis. Sweden: Uppsala University; 1995.

[20] Penzol G, Armisén PA, Fernández-Lafuente R, Rodés L, Guisán JM. Use of dextrans as long and hydrophilic spacer arms to improve the performance of immobilized proteins acting on macromolecules. Biotechnol Bioeng 1998;60:518-23.

[21] Fernández-Lafuente R, Rosell CM, Caanan-Haden L, Rodés L, Guisán JM. Facile synthesis of artificial enzyme nano-environments via solid-phase chemistry of immobilized derivatives: dramatic stabilization of penicillin acylase versus organic solvents. Enzyme Microb Technol 1999;24:96-103.

[22] Balcão VM, Fernández-Lafuente R, Malcata FX, Guisán JM Structural and functional stabilization of L-asparaginase upon immobilization onto highly activated supports. Biotechnol Prog 2001; 17:537-42.

[23] Balcão VM, Fernández-Lafuente R, Malcata FX, Guisán JM. Coimmobilization of L-asparaginase and glutamate dehydrogenase onto highly activated supports. Enzyme Microb Technol 2001;28: 696-704.

[24] Tomarelli R, Charney M, Harding M. The use of azoalbumin as a substrate in the colorimetric determination of peptic and tryptic activity. J Lab Clin Med 1949;34:428-33.

[25] Guisán JM. Aldehyde-agarose gels as activated supports for immobilization-stabilization of enzymes. Enzyme Microb Technol 1988; 10:375-82.

[26] Fernández-Lafuente R, Rodriguez V, Mateo C, Penzol G, HernandezJustiz O, Irazoqui G, et al. Stabilization of multimeric enzymes via immobilization and post-immobilization techniques. J Mol Catal B: Enzymatic 1999;7:181-9.

[27] Blanco RM, Calvete JJ, Guisán JM. Immobilization-stabilization of enzymes: variables that control the intensity of the trypsin (amino)-agarose (aldehyde) multipoint attachment. Enzyme Microb Technol 1989;11:353-9.

[28] Bastida A, Sabuquillo P, Armisen P, Fernández-Lafuente R, Huguet J, Guisán JM. A single step purification, immobilization and hyperactivation of lipases via interfacial adsorption on strongly hydrophobic supports. Biotechnol Bioeng 1998;58:486-93.

[29] Frister H, Meisel H, Richardson T. OPA method modified by use of $\mathrm{N}, \mathrm{N}$-dimethyl-2-mercaptoethylammonium chloride as thiol component. Fresenius Z Anal Chem 1988;330:631-3.

[30] Schmidt DG, Robben AJPM. OPA method for determination of the degree of hydrolysis in whey protein hydrolysates. NIZO-nieuws 1993;26:13-5.

[31] Blanco RM, Guisán JM. Stabilization of enzymes by multipoin covalent attachment to agarose-aldehyde gels: borohydride reduction of trypsin-agarose derivatives. Enzyme Microb Technol 1989;11: $360-6$.

[32] Fernández-Lafuente R, Rosell CM, Rodriguez V, Guisán JM. Strategies for enzyme stabilization by intramolecular cross-linking with bifunctional reagents. Enzyme Microb Technol 1995;17:517-23.

[33] Balcão VM, Oliveira TA, Malcata FX. Stability of a commercial lipase from Mucor javanicus: kinetic modelling of $\mathrm{pH}$ and temperature dependencies. Biocatal Biotransf 1998;16:45-66. 